\title{
PENGEMBANGAN USAHA LAMPU HIAS RUMAH UKIR BAMBU DI KABUPATEN BANGKALAN
}

\author{
Buaddin Hasan $^{1}$, Chairuddin ${ }^{2}$ \\ ${ }^{1}$ Pendidikan Matematika, Ilmu Sosial \\ ${ }^{2}$ Pendidikan Bahasa Inggris, Ilmu Sosial \\ STKIP PGRI Bangkalan \\ Email: buaddinhasan@stkippgri-bkl.ac.id
}

\begin{abstract}
Although the decorative lighting business is relatively new, handicrafts with the main bamboo material and various motifs are very popular with the community because of its unique and natural shape. In general, these decorative lights are made of materials such as glass, crystals from plastic, or stainless steel. In order to overcome the problems faced by partners, the implementation team collaborated with partners to provide various training and assistance in business development by utilizing science and technology. This community service program is carried out by the community education method, which is to provide training and mentoring to develop various designs of carving motifs using computer assistance, besides training in immersion techniques and paint finishing and drying techniques using an oven system. While the second method is the substitution of science and technology, which provides an overview of how to market products to partners in order to be able to utilize social media as a marketing tool, social media used between Blogger, IG, Facebook and WA. The results obtained in the implementation of this community partnership program were an increase in the income of bamboo carving businesses reaching $50 \%$ of the before. This happens because of the marketing system that has used social media, an increase in the production of decorative lights as much as $60 \%$ of the original production. The development of variations in carving motifs that are adjusted to the order and certain moments
\end{abstract}

Keywords: Decorative Lights, Bamboo Carvings

\begin{abstract}
Abstrak. Meski usaha lampu hias tergolong baru, kerajinan tangan dengan bahan utama bambu dan berbagai motif tersebut sangat diminati oleh masyarakat karena bentuknya yang cukup unik dan alami. Pada umumnya lampu hias ini terbuat dari bahan-bahan seperti kaca, kristal dari plastik, ataupun stainless steel. Dalam rangka mengatasi permasalahan yang dihadapi mitra, tim pelaksana bekerjasama dengan mitra memberikan berbagai pelatihan dan pendampingan dalam pengembangan usaha dengan memanfaatkan IPTEK. Program pengabdian ini dilakukan metode pendidikan masyarakat yaitu memberikan pelatihan dan pendampingan mengebangkan berbagai desain motif ukir menggunakan bantuan komputer, selain itu pelatihan teknik perendaman dan teknik finishing cat dan pengeringan menggunakan sistem oven. Sedangkan metode yang kedua adalah substitusi IPTEK yaitu memberikan gambaran cara memasarkan produk kepada mitra agar mampu memanfaatkan media sosial sebagai sarana pemasaran, media sosial yang digunakan antara Blogger, IG, Facebook dan WA. Hasil yang diperoleh dalam pelaksanaan program kemitraan masyarakat ini adalah adanya peningkatan pendapatan usaha rumah ukir bambu mencapai $50 \%$ dari semula. Hal ini terjadi karena sistem pemasaran yang sudah menggunakan media sosial, adanya peningkatan hasil produksi lampu hias sebeasar $60 \%$ dari produksi semula. Adanya pengembangan variasi motif ukir yang disesuaikan dnegan pesanan dan moment tertentu.

Kata kunci : Lampu Hias, Ukirab Bambu
\end{abstract}

\section{PENDAHULUAN}

Bambu adalah tanaman yang bisa tumbuh secara liar di berbagai daerah yang ada di Indonesia. Biasanya bambu tumbuh di hutan dan tempat yang jauh dari perkotaan, meskipun begitu bambu sangat mudah ditemukan karena tumbuhnya tidak membutuhkan perawatan. Bambu bisa tumbuh dengan subur di Indonesia karena iklim tropisnya cocok untuk jenis tanaman yang satu ini. Untuk bambu yang masih kecil saja sudah bisa dimakan dan menjadi lauk yang enak, sedangkan bambu yang sudah mulai tua bisa digunakan untuk membuat rumah penduduk, hingga kerajinan tangan yang bernilai jutaan. Meskipun kerajinan tangan dari bambu cukup sulit untuk dibuat, tetapi nilai jualnya dan nilai seni yang ada pada kerajinan tangan dari bambu 
ini membuat banyak orang tertarik untuk membuatnya.

Sumber daya alam yang dimiliki oleh masyarakat Desa Jaddih salah satunya adalah bambu. Di setiap kebun atu pinggiran rumah masyarakat di desa Jaddih notabene banyak pohon bambu yang belum dimanfaatkan oleh masyarakat setempat. Pada dasarnya bambu dapat dimanfaatkan untuk bangunan dan lain sebagainya, Namun pada faktanya, masyarakat di Desa Jaddih Socah masih belum bisa memanfaatkan bambu tersebut menjadi produk yang bernilai ekonomis tinggi. Melihat kondisi yang seperti itu perlu adanya ide kreatif untuk mengubah bambu mejadi kerajianan yang bernilai tinggi.

Pemberdayaan sumber daya manusia harus dilandasi dengan kondisi eksisting di masyarakat. Daerah yang mempunyai sumber daya alam yang melimpah terkadang tidak didukung dengan adanya pengetahuan dan keterampilan dalam pemamfaatan sumber daya alam tersebut. Untuk itu diperlukan upaya pemberdayaan masyarakat dihubungkan dengan konsep mandiri, partisipasi, jaringan kerja dan keadilan sebagai bentuk bekerjasama dengan masyarakat dalam rangka peningkatan kesejahteraan masyarakat.

Kondisi masyarakat di Desa Jaddih Kecamatan Socah Kabupaten Bangkalan lebih tergantung lahan pertanian yang kadang tidak sebanding dengan modal yang dikeluarkan. Namun pada hakikatnya banyak sumber daya alam berupa bambu yang belum mampu dimanfaatkan oleh masyarakat. Hal ini disebabkan karena tidak ada proses spesifik yang dilakukan oleh masyarakat dalam pemanfaatan sumber daya alam tersebut untuk meningkatkan nilai tambah ke level pasar lebih tinggi.

Berdasarkan hasil wawancara pelaksana pengabdian dengan mitra (pemiliK Usaha Lampu hias Rumah Ukir Bambu) mengatakan bahwa produksi lampu hiasnya bisa dikembangkan seperti halnya produk lainya. Untuk mencapi ke arah tersebut, menurut perlu adanya keterampilan dalam pengembangan desain motiv ukir dan kesesuaian dengan tema yang lagi trend, contohnya; pada saat pagelaran piala dunia, permintaan lampu hias tropi piala dunia sangat banyak. Selain itu juga perlu pemanfaatan IPTEK untuk memudahkan dalam proses produksi, diantaranya mesin cat, alat pres packing. Kemudian pemanfaatn internet untuk mencara desain yang unik dan sesuai. Dan juga perlu disain kemasan yang menarik untuk menarik minat para pembeli. Imam optimis jika peningkatan kualitas (seperti halnya diatas) ditingkatkan, apalagi ada peningkatan perbaikan dalam kemasan dan proses pemasaran yang lebih bersaing, maka nilai jualnya juga akan semakin meningkat.

Perlu adanya pemberdayaan masyarakat untuk memamfaatkan bambu menjadi barang yang bernilai rekonomi tinggi. Dalam hal ini pemberdayaan dilakukan dengan memberikan peluang usaha yang lebih baik untuk mengkreasikan bambu menjadi lampu hias yang layak jual, sehingga dengan sendirinya mereka dapat meningkatkan nilai tambah kesejahteraannya.

Adanya bambu yang melimpah di desa Jaddih Kecamatan Socah Kabupaten Bangkalan berhasil dimanfaatkan oleh pemuda setempat (Imam Syafii) menjadi kerajinan bambu ukir lampu hias. Meski tergolong baru, kerajinan tangan beraneka motif tersebut sangat diminati karena bentuknya yang cukup unik. Lampu hias merupakan salah satu ornamen yang menjadi penghias ruangan (Hasan B. , 2018)

Melihat perkembangan Kabupaten Bangkalan yang terus berupaya mengembangkan dunia pariwisata dan UMKM guna peningkatan kesejahteram masyarakat serta ketersediaan bahan baku utama bambu yang melimpah di daerah jaddih Kabupaten Bangkalan, program PKM diharapkan dapat meberikan wawasan dan pengetahuan baru kepada pemuda Kabupaten Bangkalan dalam memanfaatkan bambu menjadi kerajinan berupa lampu hias ukir sehingga berdampak pada peningkatan pendapatan perkapita masyarakat di desa Jaddih Kabupaten Bangkalan. Bahan baku utama lampu hias kreasi rumah ukir bambu adalah bambu. Bambu ditebang, kemudian diukur sesuai ukurannya, dan dilkukan proses perendaman kurang lebih 1 bulan agar tidak mudah pecah. Kemudian bambu diukir menggunakan mesin ukir. Pada proses finishing 
lampu hias ukiran bambu ini di cat menggunakan vernish dan di pasang lampu beserta saklarnya. Lampu hias ukuran kecil dijual dengan harga antar 100-150 ribu, sedangkan lampu hias ukuran $40 \mathrm{~cm}$ dijual antara 200-250 ribu.

\section{a. Aspek produksi}

Proses mengukir bambu menjadi lampu hias yang unik tidak terlalu sulit dan murah, memungkinkan masyarakat atau pemuda di Kabupaten Bangkalan untuk mengembangkan usahanya. Hal ini didukukung adanya:

1. Ketersedianya bahan utama yaitu bambu, karena sebagian besar daerah di desa Jaddih Kecamatan Socah Kabupaten Bangkalan tumbuh tanaman bambu.

2. Banyak pemuda yang tidak bekerja sehingga bisa diberdayakan dan dilatih untuk dapat memanfaatkan bambu menjadi kerajinan yang mempunyai nilai ekonomi, salah satunya lampu hias ukir bambu

3. Biaya produksi yang murah, karena tersedianya bahan baku yang melimpah.

\section{b. Aspek Manajemen usaha}

Untuk menjamin

ketercapaian pengembangan produksi kerajinan lampu kreasi bambu. Pelaksana bersama dengan mitra menyusun manajemen usaha dengan melihat beberapa aspek, diantaranya;

1. Aspek kualitas, dalam produksi lampu hias kreasi bambu mitra selalu konsisten menjaga kualitas produk, sehingga dapat menjaga kepercayaan pembeli dan bisa laku di pasaran. Terdapat pengaruh yang kuat dan positif antara kualitas layanan terhadap loyalitas pelanggan (Aryani, 2011). Kualitas produk dan lokasi terbukti secara positif dan signifikan Mempengaruhi konsumen dalam keputusan pembelian suatu barang (Ghanimata, 2012).

2. Aspek packing, proses pengemasan produk didesain semenarik mungkin agar dapat menarik minat pembeli. Packaging (kemasan) serta icon produk dapat mempengaruhi konsumen dalam keputusan pembelian suatu barang (Hariadi, 2015).

3. Aspek pemasaran, lokasi kabupaten Bangkalan yang strategis dengan adanya jembatan suramadu menjadikan proses pemasaran lampu hias kreasi rumah ukir bambu yang sangat menjanjikan, proses pemasaran produk dapat dilakungan melalui: (1) Mendirikan stand rumahan, (2) distribusi ke toko tempat wisata di Bangkalan, (3) pemasaran melalui media sosial (Blog rumah ukir bambu, Google, FB, BBm, WA, Instagram).

4. Aspek harga, harga penjualan lampu hias kreasi rumah ukir bambu disesuaikan dengan harga dipasaran sehingga mampu bersaing.

\section{c. Sumber Daya Manusia}

Untuk mendukung keberlangsungan produksi lampu hias rumah ukir bambu juga didukung dengan sumber daya yang memadai yaitu sumber daya manusia. Produksi lampu hias rumah ukir bambu tidak memerlukan keahlian khusus, hanya dengan mengandalkan keuletan dan ketelatenaan para karyawan mampu memproduksi lampu hias dengan baik. Pemberdayaan pemuda atau remaja di Desa Jaddih Kabupaten Bangkalan sangat memungkinkan untuk direkrut menjadi tenaga kerja, disamping itu proses produksi tidak telalu sulit sehingga pelaksana dapat memberikan pelatihan dan pendampingan dalam produksi, pengembangan motif ukir, finishing cat, packinging, dan dalam proses manajemen dan pemasaran hasil produksi. Sumber daya manusia yang terampil, tekun dan ulet berpengaruh terhadap hasil produksi (Hasan B. R., 2018)

\section{d. Sumber Daya Alam}

Desa Jaddih Kecamatan Socah Kabupaten Bangkalan sebagian besar merupakan dataran dengan suhu yang panas, sehingga tanaman bambu banyak tumbuh di daerah tersebut. Hal ini yang menjadikan produksi lampu hias rumah ukir bambu terus berkembang tanpa kekurangan bahan baku utama.

\section{METODE PELAKSANAAN}

Dalam rangka menjamin kesuksesan pelaksanaan program pengabdian ini, metode yang dilakukan dibagai tahapan, yaitu:

\section{a. Tahap Persiapan}

Pada tahapan ini tim pelaksana melakukan diskusi bersama mitra membahas persiapan yang diperlukan untuk memulai pelaksanaan program PKM. pelaksana 
menyusun jadwal pelatihan dan pendampingan serta mencoba mendisain dan membuat alat yang dibutuhkan dalam proses pelaksanaan program pengabdian ini.

\section{b. Tahap Pelaksanaan}

Pada tahap pelaksanan, pelaksana bersama mitra melakukan langkah metode yang akan diterapkan, antara lain;

\section{Metode Pendidikan Masyarakat}

Metode ini dilakukan memberikan pelatihan dan pendampingan dalam memanfaatkan bambu menjadi lampu hias. Serta pengembangan berbagai motif ukir. Metode ini dilakukan di tempat usaha mitra selama kurang lebih 5 hari dengan dibantu oleh 4 orang karyawan, 1 anggota pengabdian dan 5 orang mahasiswa sebagai pembantu lapangan.
Adapun materi pelatihan dan pendampingan ini antara lain:

a). Pelatihan perendaman bambu

Langkah pertama yang dilakukan oleh pelaksana beersama mitra adalah memilih bambu yang akan dijadikan lampu hias, pemilihan ini dilakukan agar mendpatkan bambu yang bagus sesuai dengan pesanan. Kemudian dilakukam pemotongan bambu dengan menggunakan alat pemotong gergaji mesin dengan ukuran antara $40-50 \mathrm{~cm}$ sesuai dengan lampu yang diingikan. Setelah dilakukan pemotong bambu direndam dalam bak berisi air dengan menggunakan campuran cairan kimia selama lebih kurang 1 bulan, hal ini dilakukan agar bambu tidak mudah pecah pada saat diukir
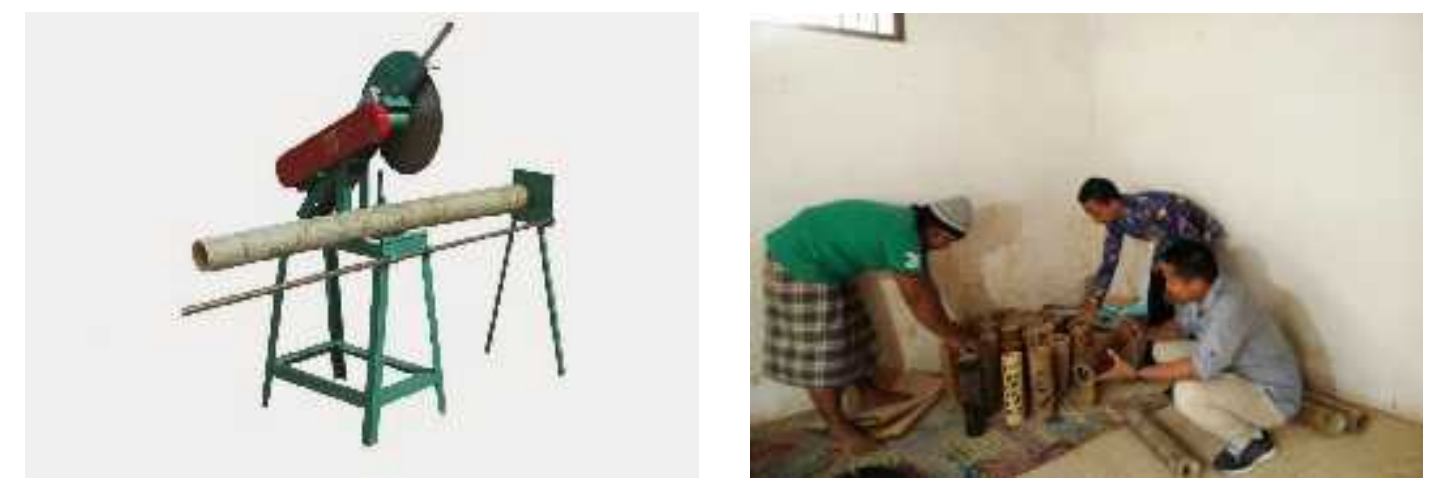

Gambar 1. Alat Pemotong Bambu dan Hasil Pemilihan Bambu

b). Pelatihan pengembangan motif ukir

Dalam pengembangan motif ukir lampu hias pelaksana pengabdi memberikan pelatihan dan pendampingan kepada mitra. Proses pelatiha dilakukan di rumah mitra dengan 4 orang karyawannya. Sebelum mengembangkan motif ukir pelaksana pengabdi memberikan penjelasan bagaimana cara mendisain motif, kembali kepada tujuannya motif ukir harus disesuaikan dengan pesanan, motif ukir juga harus mengikuti moment tertentu misalnya demam piala dunia, jadi motif ukir menyesuaikan dengan moment tersebut. Cara membuat motif ukir dilakukan dengan cara searching motif di internet kemudian diprint dan dicetak pada kertas. Cetakan tersebut selanjutnya ditempel pada bambu yang sudah direndam untuk dilakukan jiplak motif menggunakan spidol. Setelah bentuk motif rapi pada bambu kemudian dilakukan pengeboran menggunakan mata bor chun sehingga bentuk ukiran lebih bagus dan rapi.

Proses pelatihan dan pendampingan ini dilakukan selama 1 hari sampai mitra benarbenar mapu melakukan proses pengukiran dengan baik

c). Pelatihan penghalusan lampu hias

Berbeda dengan pelatihan pengembangan motif ukir. Pelatihan penghalusan bambu dialkukan sangat mudah. Alat yang digunakan adalah grinda mesin dengan ukuran tingkat kehaluasan yang berbeda. Hal ini dilakukan agar memperoleh hasil yang maksimal.Poses pelatihan dilakukan di rumah mitra dengan karyawannya dan dibantu oleh mahasiswa. 

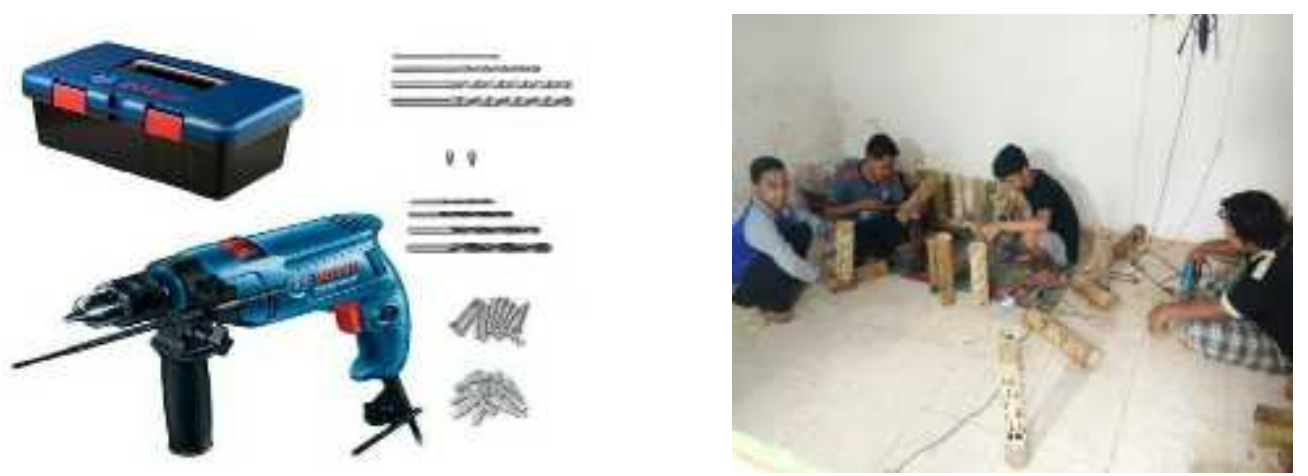

Gambar 2. Alat Bor Ukiran Bambu dan Proses Disain Ukir Bambu
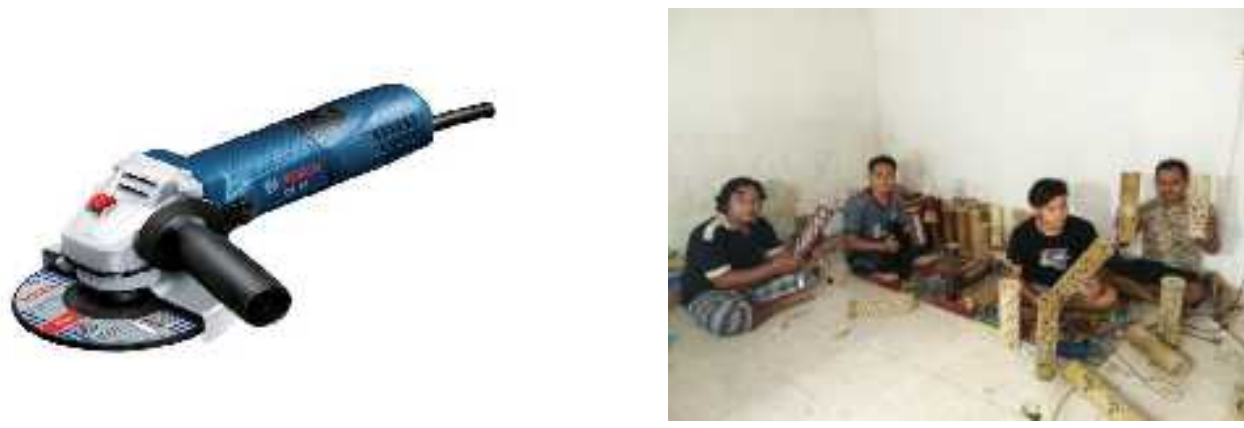

Gambar 3 Mesin Penghalus dan Hasil

d). Pelatihan cat menggunakan sistem open

Tahap akhir dalam proses produksi adalah finishing cat. Program pelatihan dan pendampingan finishing cat di lakukan di rumah mitra dengan dibantu 5 orang mahasiswa dan 4 orang karyawan rumah ukir bambu. Alat dan bahan yang diperlukan dalam kegiatan ini antara lain; kompresor cat, open pengeringan, sedangkan bahannya terdiri dari cat pernis dan tinner spesial. Proses pelaksanaan pelatihan diawali dengan mengecat bagian lampu hias dengan cat pernis menggunakan kompresor cat yang sudah dimodifikasi. Setelah seluruh bagia lampu hias terlapisi dengan cat secara merata kemudian dilakukan pengeringan. Proses pengeringan dilakukan dengan sistem open lampu hias yang dibuat khusus menggunakan lampu 15 waat sebanyak 12 buah bohlamp. Hal ini dilakukan agar panas merata sehingga hasil pengecatan bagus.

e). Pelatihan pengemasan lampu hias Langkah akhir adalah proses pakaging, proses ini dilakukan untuk menjaga kualitas dan benturan lampu hias pada saat pengiriman lampu kepada konsumen. Proses pakaging juga menjadi salah satu daya tarik dan kepuasan konsumen kepada produsen. Sehingga pakaging dilakukan sebaik mungkin.
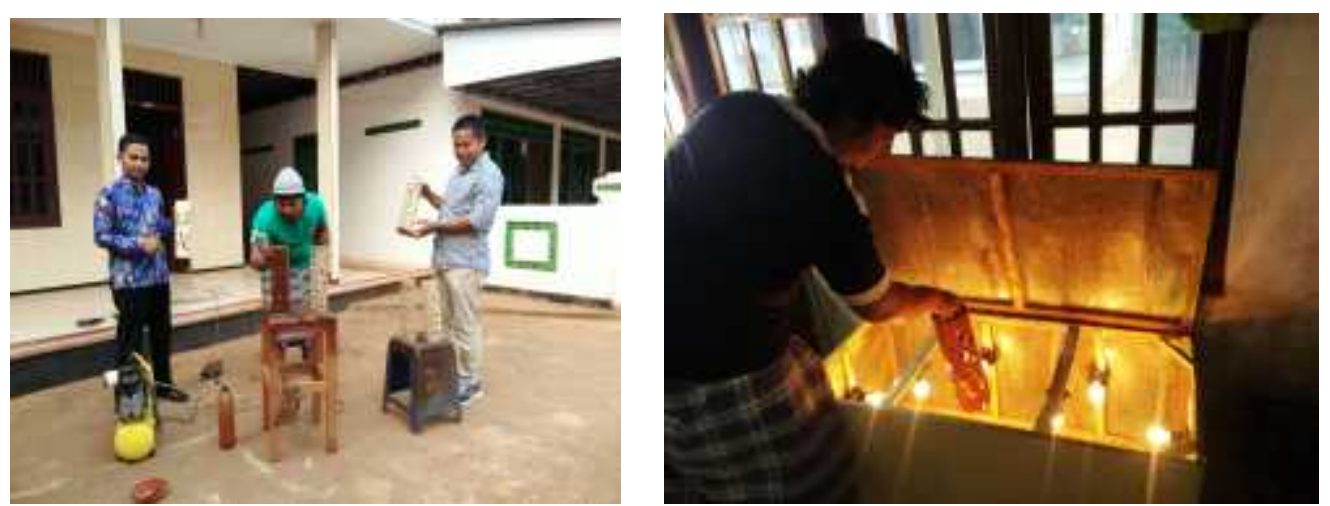

Gambar 4. Proses Finishing Cat dengan Kompresor dan Pengeringan Menggunakan Open 

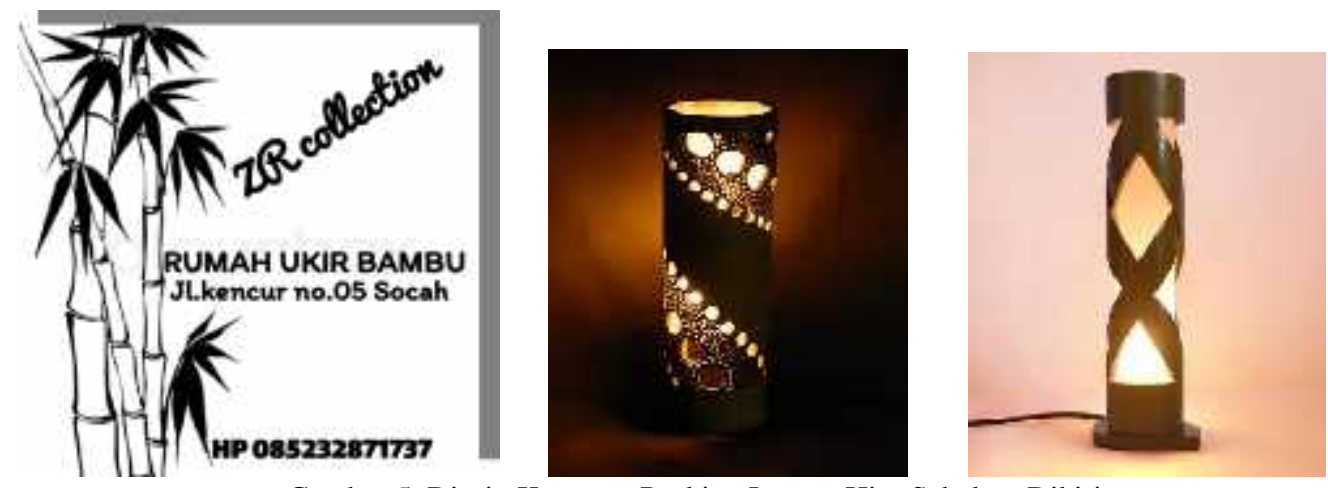

Gambar 5. Disain Kemasan Packing Lampu Hias Sebelum Dikirim

\section{Metode Substitusi IPTEK}

Metode ini memberikan gambaran cara memasarkan produk dan melakukan pendampingan sampai mitra mampu memasarkan produk dengan baik sebagai bentuk implementasi co-benefit. Dalam metode ini pelaksana melakukan pendampingan kepada mitra dalam memanfaatkan media sosial dan media rekanan untuk memasarkan produk, serta melatih untuk dapat bermitra dengan toko- toko pusat oleh-oleh di Kabupaten Bangkalan. IPTEK yang dimanfaatkan sebagai media pemasaran, diantaranya; media facebook. WA, BBM, IG dan sebagainya. Adanya pemasaran yang sesuai dengan perkembangan jaman, misalnya media online, pemasaran produk semakin berkembang yang berdampak pada peningkatan hasil usaha (Hasan, B \& Rizkiana, A, 2018).
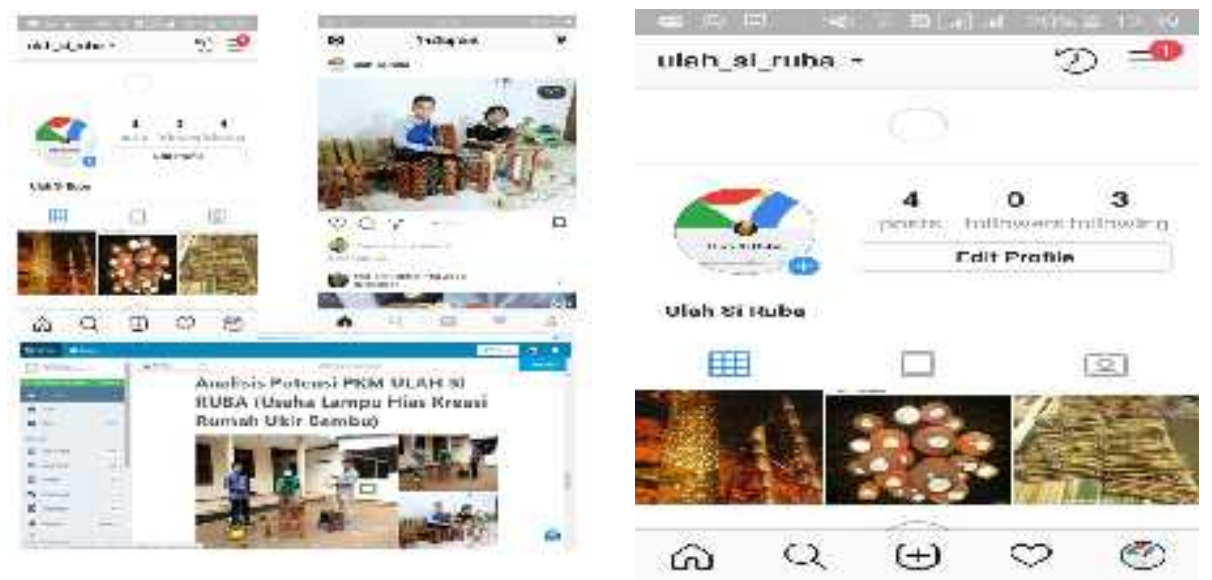

Gambar 6. Media Promosi Lampu Hias Rumah Ukir Bambu

\section{HASIL DAN PEMBAHASAN}

Dalam pelaksanaan pengabdian kepada masyarakat ini, hasil yang dikembangkan berupa lampu hias kreasi bambu, bahan baku utama dalam program pengabdian ini adalah bambu. Dalam produksi lampu hias mitra dibantu oleh beberapa teman kerja yang mayoritas adalah pemuda yang ada di desa jaddih barat. Dalam setiap bulan usaha lampu kreasi bambu ini mampu memproduksi 15-25 unit lampu hias yang dijual berdasarkan pesanan. Hal ini dirasakan ada peningkatan dari segi produksi dan kualitas produksi, serta pemintaan konsumen. Hasil produksi usaha lampu hias kreasi rumah bambu ini mempunyai keunggulan tersendiri dibanding dengan lampu hias yang lain

1. Motif ukir yang bervariasi sesuai dengan pesanan dan momen-momen tertentu.

2. Lampu hias kreasi rumah ukir bambu ini tidak mudah pecah karena proses pembuatannya menggunakan teknik perendaman selama kurang lebih 1 bulan sampai akhirnya bambu siap diukir

3. Cat pernis halus dan tidak mudah luntur, karena dalam proses finishing pemilik usaha ini menggunakan metode pengeringan menggunakan sistem open dengan pemanas 12 bohlamp 15 watt.

Program pengabdian kepada masyarakat ini memberikan danpak positif kepada mitra. 
Program ini dirasakan sangat membantu dalam proses pengembangan produksi lampu hias rumah ukir bambu, adapun dampak yang dirasakaan secara langsung oleh mitra program penagbdian kepada masyarakat ini antara lain:
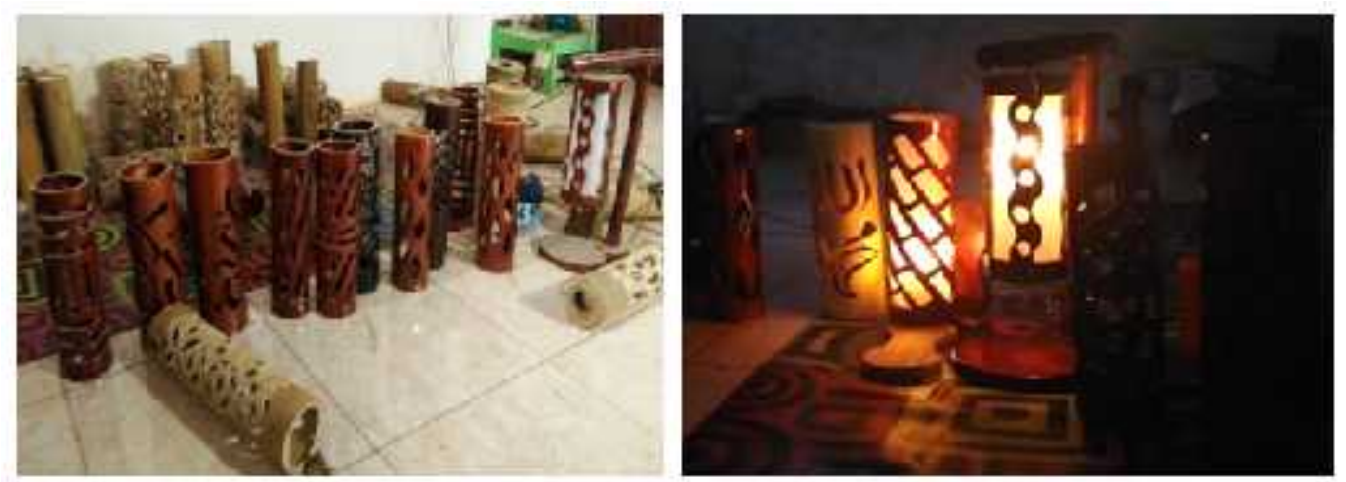

Gambar 6. Hasil Produksi Lampu Hias Rumah Ukir Bambu

Tabel 1. Perkembangan Usaha Lampu Hias Rumah Ukir Bambu dalam Pelaksanaan Program Kemitraan Masyarakat

\begin{tabular}{|c|c|c|c|c|}
\hline \multirow[b]{2}{*}{ No } & \multirow[b]{2}{*}{ Indikator } & \multicolumn{2}{|c|}{ Perkembangan Usaha Rumah Ukir Bambu } & \multirow[t]{2}{*}{ Keterangan } \\
\hline & & $\begin{array}{l}\text { Sebelum } \\
\text { Pelaksanaan PKM }\end{array}$ & $\begin{array}{l}\text { Sesusdah } \\
\text { Pelaksanaan PKM }\end{array}$ & \\
\hline 1 & $\begin{array}{l}\text { Jumlah Produksi } \\
\text { /bulan }\end{array}$ & 10-15 lampu hias & 15-25 lampu hias & $\begin{array}{l}\text { Hal ini terjadi karena } \\
\text { sistem pemasaran sudah } \\
\text { modern. }\end{array}$ \\
\hline 2 & Motif Ukir & Statis & $\begin{array}{l}\text { Bervariasi ragam } \\
\text { motif ukir }\end{array}$ & $\begin{array}{lr}\text { Terjadi karena } & \text { motif } \\
\text { ukir } & \text { sudah } \\
\text { menggunakan } & \text { sitem } \\
\text { komputerisasi } & \text { dan } \\
\text { sesuai pesanan, } & \text { serta } \\
\text { mengikuti moment } & \\
\text { tertentu } & \end{array}$ \\
\hline 3 & Pemasaran & $\begin{array}{l}\text { Berdasarkan } \\
\text { Pesanan }\end{array}$ & $\begin{array}{l}\text { Via media sosial } \\
\text { (IG, Facebook, } \\
\text { Blogger, WA) dan } \\
\text { pesanan }\end{array}$ & $\begin{array}{l}\text { Sistem pemasaran via } \\
\text { medsos lebih luas } \\
\text { sehingga } \\
\text { dikenal oleh konsumen }\end{array}$ \\
\hline 4 & $\begin{array}{l}\text { Manajemen } \\
\text { keuangan }\end{array}$ & Tanpa pembukuan & $\begin{array}{l}\text { Menggunakan } \\
\text { pembukuan } \\
\text { sederhana }\end{array}$ & $\begin{array}{ll}\text { Mampu } & \text { memisahkan } \\
\text { keuangan } & \text { usaha dan } \\
\text { pribadi } & \end{array}$ \\
\hline
\end{tabular}

\section{SIMPULAN DAN SARAN}

Dari pelakasanaan program masyarakat ini dapat disimpulkan hal sebagi berikut:

1. Peningkatan pendapatan usaha rumah ukir bambu mencapai $50 \%$ dari semula. Hal ini terjadi karena sistem pemasaran yang sudah menggunakan media sosial

2. Adanya peningkatan hasil produksi lampu hias kreasi rumah bambu sebeasar $60 \%$ dari produksi semula.
3. Adanya pengembangan variasi motif ukir yang disesuaikan dnegan pesanan dan moment tertentu

\section{UCAPAN TERIMAKASIH}

Kami pelaksana pengabdian kepada masyarakat mengucapkan terimakasih kepada DRPM KEMENRISTEKDIKTI yang telah membiayai program PKM ini. Semoga program 
ini dapat bermanfaat bagi pengembangan UMKM untuk kedepannya.

\section{DAFTAR PUSTAKA}

Aryani, D. \&. (2011). Pengaruhkualitas layanan terhadap kepuasan pelanggan dalam membentuk loyalitas pelanggan. Jurnal Ilmu Administrasi dan Organisasi, BISNIS \& BIROKRASI:, 17(2).

Ghanimata, F. \&. (2012). Analisis pengaruh harga, kualitas produk, dan lokasi terhadap keputusan pembelian (studi pada pembeli produk bandeng juwana elrina semarang. Semarang: Fakultas Ekonomika dan Bisnis.

Hariadi, D. (2015). Pengaruh produk, harga, promosi dan distribusi Terhadap keputusan pembelian konsumen Pada produk projector microvision. Jurnal Ilmu \& Riset Manajemen, 1(8).
Hasan, B. \&. (2018). PENGEMBANGAN USAHA MIKRO KERUPUK KERANG MADURASA (PRODUK MADURA CITARASA NUSANTARA) DI KABUPATEN BANGKALAN. In Seminar Nasional Hasil Pengabdian Kepada Masyarakat (hal. (Vol. 2, No. 1, pp. 37-41)). Pamekasan: Universitas Islam Madura.

Hasan, B. (2018). Manajeman Produksi Usaha Lampu Hias Kreasi Bamboo di Kabupaten Bangkalan Propinsi Jawa Timur. JAST: Jurnal Aplikasi Sains dan Teknologi, 2(2), 88-94.

Hasan, B. R. (2018). Varian Produksi, Manajemen Keuangan dan Pemasaran Usaha Mikro Kerupuk Kerang Madurasa di Kabupaten Bangkalan. International Journal of Community Service Learning, Vol. 2 no. 3 . 